Mechanism of Thermal Reversal of the (Fulvalene)tetracarbonyldiruthenium Photoisomerization: Toward Molecular Solar-Thermal Energy Storage

Y. Kanai, V. Srinivasan, S.K. Meier, K.P.C. Vollhardt, J.C. Grossman

February 22, 2010

Angewandte Chemie International Edition 
This document was prepared as an account of work sponsored by an agency of the United States government. Neither the United States government nor Lawrence Livermore National Security, LLC, nor any of their employees makes any warranty, expressed or implied, or assumes any legal liability or responsibility for the accuracy, completeness, or usefulness of any information, apparatus, product, or process disclosed, or represents that its use would not infringe privately owned rights. Reference herein to any specific commercial product, process, or service by trade name, trademark, manufacturer, or otherwise does not necessarily constitute or imply its endorsement, recommendation, or favoring by the United States government or Lawrence Livermore National Security, LLC. The views and opinions of authors expressed herein do not necessarily state or reflect those of the United States government or Lawrence Livermore National Security, LLC, and shall not be used for advertising or product endorsement purposes. 


\title{
Mechanism of Thermal Reversal of the (Fulvalene)tetracarbonyldiruthenium Photoisomerization: Toward Molecular Solar-Thermal Energy Storage
}

\author{
Yosuke Kanai, ${ }^{*} \dagger$ Varadharajan Srinivasan, ${ }^{\ddagger}$ Steven K. Meier, ${ }^{\S}$ K. Peter C. Vollhardt, ${ }^{*}{ }^{\S}$ Jeffrey C. Grossman ${ }^{*, *}$ \\ Condensed Matter and Materials Division, Lawrence Livermore National Laboratory, Livermore, California 94554, \\ Department of Materials Science and Engineering, Massachusetts Institute of Technology, Cambridge, Massachusetts \\ 02139, and Department of Chemistry, University of California at Berkeley, Berkeley, CA 94720
}

RECEIVED DATE (automatically inserted by publisher); E-mail: ykanai@IInl.gov, kpcv@berkeley.edu, jcg@mit.edu

In the currently intensifying quest to harness solar energy for the powering of our planet, most efforts are centered around photoinduced generic charge separation, such as in photovoltaics, water splitting, other small molecule activation, and biologically inspired photosynthetic systems. ${ }^{1}$ In contrast, direct collection of heat from sunlight has received much less diversified attention, its bulk devoted to the development of concentrating solar thermal power plants, in which mirrors are used to focus the sun beam on an appropriate heat transfer material. ${ }^{2}$ An attractive alternative strategy would be to trap solar energy in the form of chemical bonds, ideally through the photoconversion of a suitable molecule to a higher energy isomer, which, in turn, would release the stored energy by thermal reversal. Such a system would encompass the essential elements of a rechargeable heat battery, with its inherent advantages of storage, transportability, and use on demand. ${ }^{3}$ The underlying concept has been explored extensively with organic molecules (such as the norbornadiene-quadricyclane cycle) ${ }^{4}$ often in the context of developing photoswitches. ${ }^{5}$ On the other hand, organometallic complexes have remained relatively obscure in this capacity, ${ }^{6}$ despite a number of advantages, including expanded structural tunability and generally favorable electronic absorption regimes. A highly promising organometallic system is the previously reported, robust photo-thermal fulvalene (Fv) diruthenium couple $\mathbf{1} \leftrightarrows 2$ (Scheme 1). ${ }^{7}$ However, although reversible and moderately efficient, lack of a full, detailed atom-scale understanding of its key conversion and storage mechanisms have limited our ability to improve on its performance or identify optimal variants, such as substituents on the Fv, ligands other than $\mathrm{CO}$, and alternative metals. Here we present a theoretical investigation, in conjunction with corroborating experiments, of the mechanism for the heat releasing step of $\mathbf{2} \rightarrow \mathbf{1}$ and its $\mathrm{Fe}(\mathbf{4})$ and Os (6) relatives. The results of the combined study has enabled a rigorous interpretation of earlier and new experimental measurements and paint a surprising picture. First-principles calculations were employed based on spin unrestricted density functional theory (DFT) with a non-empirical gradient corrected exchange-correlation functional ${ }^{8}$. Ultrasoft pseudopotentials ${ }^{9}$ were used to describe the valence-core interactions of electrons, including scalar relativistic effects of the core. Wavefunctions and charge densities were expanded in plane waves with kinetic energies up to 25 and 200 Rydberg, respectively. Reaction pathways were delineated with the string method, ${ }^{10}$ as implemented ${ }^{11 \mathrm{a}}$ within the Car- Parrinello approach. ${ }^{11 \mathrm{~b}}$ This method allows for the efficient
Scheme 1. Photoisomerizations of

(Fulvalene)tetracarbonyldimetals and Their Thermal Reversal
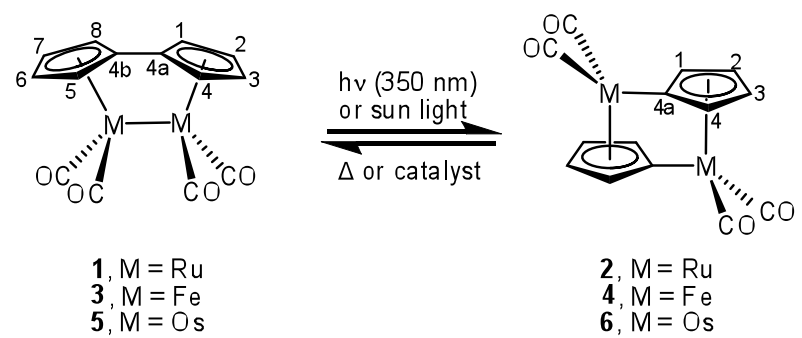

determination of the minimum energy path (MEP) of atomistic transitions and thus also saddle points (transition states, TSs), which are the energy maxima along the MEP. All geometries were optimized until all forces on the atoms were less than $0.02 \mathrm{eV} / \AA$. The calculated structures of $\mathbf{1}$ and $\mathbf{2}$ were in good agreement with their experimental counterparts [for example (calculated/averaged experimental): $1 \mathrm{Ru}-\mathrm{Ru}$ 2.89/2.82, $\mathrm{Cp}_{\text {centroid }} \mathrm{Ru}$ 1.93/1.89, $\mathrm{C}_{4 \mathrm{a}}-\mathrm{C}_{4 \mathrm{~b}}$ 1.45/1.46 $\AA$; Fv bend 27.8/28.5 ○; $2 \mathrm{Ru}-\mathrm{Ru}$ 3.53/3.47, Cp centroid $\mathrm{Ru} 1.93 / 1.89$, C4a-C4b 2.66/2.64 $\AA$; $\mathrm{Cp}_{\text {centroid }}-\mathrm{C}_{4 \mathrm{a}}-\mathrm{Ru}_{\sigma \text {-bound }} 162.8 / 162.1{ }^{\circ}$; see also Supporting Information]. ${ }^{7}$

For the mechanism of the conversion of $\mathbf{2}$ to $\mathbf{1}$, our calculations reveal an enthalpy (neglecting the small temperature dependence) of $20.8 \mathrm{kcal} \mathrm{mol}^{-1}$, in excellent agreement with experiment, $19.8 \pm 1.4 \mathrm{kcal} \mathrm{mol}^{-1}$. $^{7,12}$ This value corresponds to an energy density of $\sim 0.2 \mathrm{MJ} / \mathrm{kg}$, comparable to that of lithium ion batteries, $\sim 0.5 \mathrm{MJ} / \mathrm{kg}$. Analyzing the computed MEP, a two step process was uncovered, in which 2 rearranges by initial $\mathrm{Cp}-\mathrm{Cp}$ coupling via TS $\mathbf{A}$ to deliver biradical intermediate $\mathbf{B}$, which in turn proceeds through TS $\mathbf{C}$ to $\mathbf{1}$ (Figure 1). The underlying energetics are depicted in Figure 2. Proceeding along this reaction coordinate, the first step defines a preequilibrium and involves an unusual TS structure (A), $22.4 \mathrm{kcal} \mathrm{mol}^{-1}$ above 2 (Figure 1). It can be viewed as a pseudo-triple decker complex, in which the bridging $\mathrm{Fv}$ ligand contains two nearly planar $\mathrm{Cp}$ halves twisted by $46.3^{\circ}$ with respect to each other. The nascent C-C bond distance is $1.54 \AA$, elongated, but well on the way to that in $\mathbf{B}(1.43 \AA)$. This connection, featuring two formally pentavalent carbon atoms, bridges the two $\mathrm{Ru}$ atoms unsymmetrically, each side exhibiting a short $(2.21,2.21 \AA)$ and a long $\mathrm{Ru}-\mathrm{C}$ linkage $(2.39,2.43 \AA)$. A tantalizingly close topological analogy was found in the structure of the isoelectronic anti- $\mathrm{Cp}_{2} \mathrm{Ru}_{2}(\mu$-cyclooctatetraene), in which the 


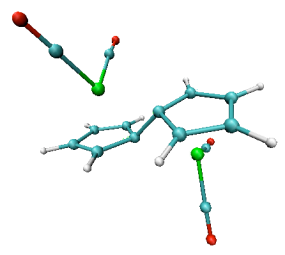

A

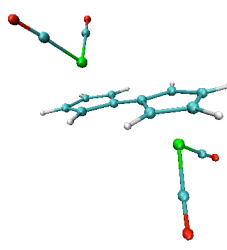

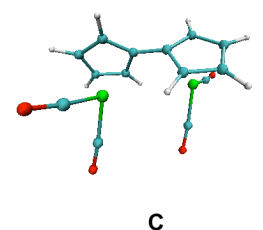

C
Figure 1. Key structures along the minimum energy path for the thermal reversal reaction of $\mathbf{2}$ to $\mathbf{1}$. $\mathbf{A}$ and $\mathbf{C}$ correspond to transition states, while $\mathbf{B}$ is an intermediate in the reaction. Blue, red, white, and green atoms correspond to carbon, oxygen, hydrogen, and ruthenium, respectively. See Supporting Information for key structural parameters.

corresponding bond $[1.57 \AA]$ is also reversibly cleaved, but only on two-electron oxidation-reduction. ${ }^{13}$ Diradical B lies $18.0 \mathrm{kcal} \mathrm{mol}^{-1}$ above 2. Equating the $\mathrm{Cp}-\mathrm{Cp}$ bond energy in $\mathbf{B}$ to that in biphenyl $\left(118 \mathrm{kcal} \mathrm{mol}^{-1}\right)^{14}$ provides an estimate of the $\mathrm{Cp}$-Ru $\sigma$-bond strength of $68 \mathrm{kcal} \mathrm{mol}^{-1}$. ${ }^{15}$ The structure of B features the anti- $-\mathrm{VMM}_{2}$ configuration, with a pyramidalized $\mathrm{Ru}$ stereochemistry $\left[\mathrm{Cp}_{\text {centroid }}-\mathrm{Ru}-\left(\mathrm{C}_{\mathrm{C} \equiv \mathrm{O}^{-}}-\mathrm{C}_{\mathrm{C} \equiv \mathrm{O}}\right)_{\text {centroid }}=161.2^{\circ}\right)$ that is similar to that observed in the crystallographically characterized, isoelectronic $17 \mathrm{e} \mathrm{Cp} * \mathrm{Fe}\left(\right.$ dppe) $\left(167.8^{\circ}\right) .^{16}$ Surprisingly, in light of the normally diffusion-controlled dimerization of $17 \mathrm{e} \mathrm{CpM}$ species, ${ }^{17}$ the rate determining step of the thermal reversal of $\mathbf{2}$ is controlled by the steric hindrance of the rotation of the $\mathrm{Cp}-\mathrm{Cp}$ bond, ${ }^{18} 11.7 \mathrm{kcal} \mathrm{mol}^{-1}$, before the formation of the $\mathrm{Ru}-\mathrm{Ru}$ bond, as indicated by $\mathbf{C}$. Here, the $\mathrm{Cp}-\mathrm{Cp}$ distance lengthens to $1.48 \AA$, thus minimizing the encumbered $\mathrm{Ru}-\mathrm{CpH} \alpha$ interaction, $2.66 \AA$, still well within van der Waals distance. ${ }^{19}$

The measured barrier for the thermal reversal reaction from 2 to $\mathbf{1}$ is $29.9 \pm 2 \mathrm{kcal} \mathrm{mol}^{-1}$. To address this quantity computationally, we solved numerically a set of rate equations for $\mathbf{2} \leftrightarrows \mathbf{B} \leftrightarrows \mathbf{1}$, using the calculated reaction energetics (see Supporting Information). The preequilibrium between $\mathbf{2} \leftrightarrows \mathbf{B}$ was found to be established extremely quickly, and the effective barrier from 2 to $\mathbf{1}$ computed at $29.7 \mathrm{kcal} \mathrm{mol}^{-1}$, corresponding to the energy difference between $\mathbf{2}$ and $\mathbf{C}$. Conversely, the barrier for bond dissociation in $\mathbf{1}$ is calculated at $50.5 \mathrm{kcal} \mathrm{mol}^{-1}$, consistent with the extraordinary thermal stability of this compound (mp 288-290 ${ }^{\circ} \mathrm{C}$ ), and the computed $\mathrm{Ru}-\mathrm{Ru}$ bond strength (estimated from the energy difference between $\mathbf{B}$ and 1) is $38.8 \mathrm{kcal} \mathrm{mol}^{-1}$, close to a value previously suggested $\left(35 \mathrm{kcal} \mathrm{mol}^{-1}\right){ }^{7}$

An important consequence of the computed mechanism is the presence of a preequilibrium $\mathbf{2} \leftrightarrows \mathbf{B}$ on the way to $\mathbf{1}$, a facet that explains some peculiar experimental observations. ${ }^{7}$ Thus, the observed accelerated disappearance of 2 with added $\mathrm{CCl}_{4}$ and concomitant appearance of $\mathrm{FvRu}_{2}(\mathrm{CO})_{4} \mathrm{Cl}_{2}$ as a product, can now be rationalized by the competitive trapping of $\mathbf{B}$ with the additive. Indeed, a reinvestigation of this reaction in toluene charged with increasing amounts of $\mathrm{CCl}_{4}$ at $70{ }^{\circ} \mathrm{C}$ revealed saturation kinetics from which a $\Delta G_{70}^{\neq}=22.9( \pm 0.8)$ $\mathrm{kcal} \mathrm{\textrm {mol } ^ { - 1 }}$ was obtained. This value is consistent with the calculated barrier of $\Delta H_{\mathrm{DFT}}^{\neq}=22.4 \mathrm{kcal} \mathrm{mol}^{-1}$ for the preequilibrium step (A; Scheme 1),.Finally, one notes that the barrier for $\mathbf{B}$ reverting to $\mathbf{2}$ is only $4.4 \mathrm{kcal} \mathrm{mol}^{-1}$, reviving the initially discounted possibility that the photochemical step from $\mathbf{1}$ to $\mathbf{2}$ also passes through the intermediacy of $\mathbf{B} .^{7}$ The finding that $\mathrm{CCl}_{4}$ as a solvent does not affect its outcome may simply be due

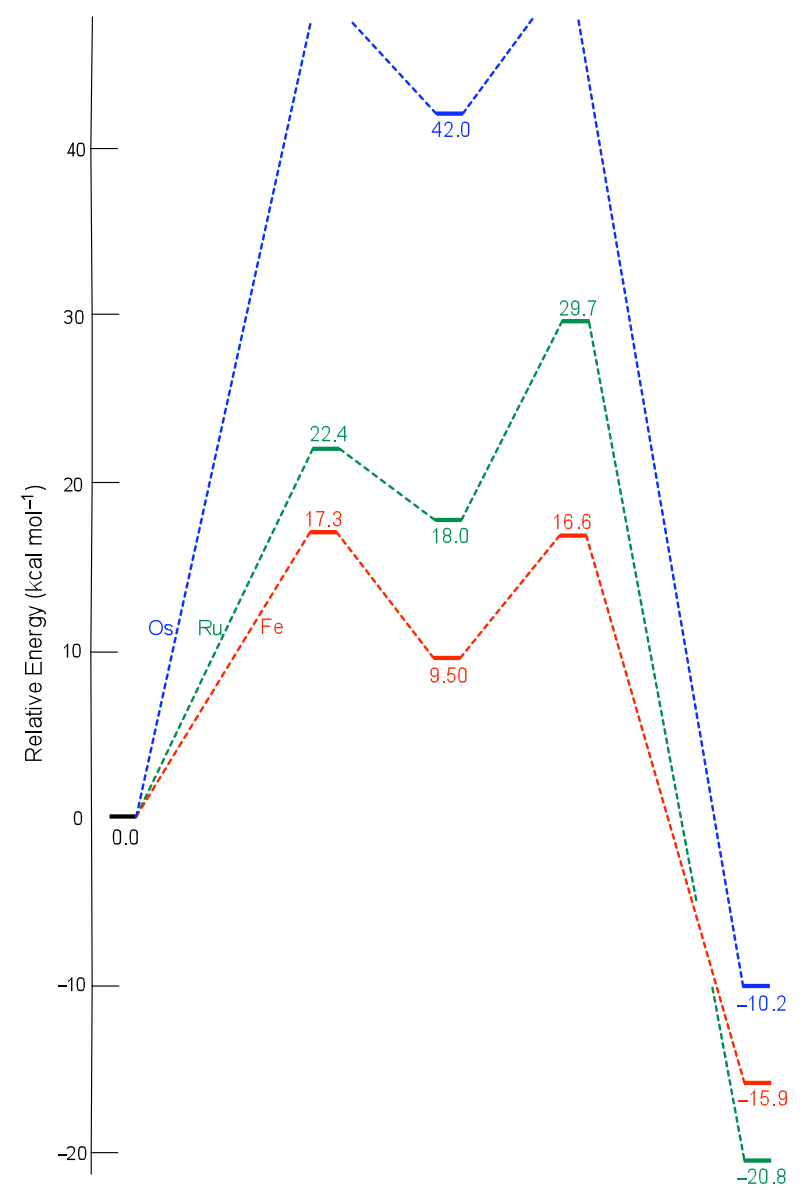

Figure 2. Calculated potential energy profiles (kcal mol-1) for the thermal reversal reactions of the photoisomers 2 $(\mathrm{Ru}$; green), 4 (Fe; red), and $\mathrm{Os}(6 ;$ blue $)$ to the corresponding (fulvalene)tetracarbonyldimetals. $\mathbf{A}$ and $\mathbf{C}$ correspond to transition states, while $\mathbf{B}$ is an intermediate in the reaction. See the Supporting Information for the structural evolution of $\mathbf{2}$ along the minimum energy path.

to noncompetitive intermolecular trapping kinetics at room temperature.

To further explore the scope of the photothermal system, in particular the possibility of using the cheaper and environmentally and economically more agreeable Fe analogs, the potential energy manifold of $\mathbf{3} \leftrightarrows \mathbf{4}$ and, for completion of the triad elements, briefly also $\mathbf{5} \leftrightarrows \mathbf{6}$, were scrutinized (Scheme 1). For the former, the photochemical energy storage potential is diminished relative to its $\mathrm{Ru}$ relative, $15.9 \mathrm{kcal} \mathrm{mol}^{-1}$. In addition, the rate determining transition state is now that of the first step leading to the biradical and the computed effective barrier is much smaller $\left(17.3 \mathrm{kcal} \mathrm{mol}^{-1}\right)$. Consequently, the nature of the thermal reversal reaction changes for the Fe case, and its significantly lower thermal stability might preclude the isolation of photoisomer 4. Experimentally, the 2,3,6,7-tetratert-butyl derivative of $\mathbf{3}$ was observed to be (seemingly) photoinert, possibly because of fast thermal reversal at the ambient temperatures employed. ${ }^{20}$ Indeed, the computed rate for this process is several orders of magnitude larger at room temperature compared to its $\mathrm{Ru}$ analog (see Supporting Information). 
The computations also give an estimate of the FvFe-Fe bond strength, $25.4 \mathrm{kcal} \mathrm{mol}^{-1}$, comparable to that in $\left[\mathrm{CpFe}(\mathrm{CO})_{2}\right]_{2}, 26.9 \pm 2.7 \mathrm{kcal} \mathrm{mol}^{-1} .^{21}$ In comparison, the Os system is estimated to be an even poorer photoenergy storage molecule $\left(10.2 \mathrm{kcal} \mathrm{mol}^{-1}\right)$ and appears to traverse a prohibitively energetic reversal manifold, as judged from the high energy of the diradical intermediate $\left(42 \mathrm{kcal} \mathrm{mol}^{-1}\right.$ above 6; approximate Os-Os bond strength $\left.52.2 \mathrm{kcal} \mathrm{mol}^{-1}\right)$. $^{22}$ Given these findings, an MEP for the Os case was not addressed. Preliminary experiments reveal that the 2,3,6,7-tetra-tert-butyl derivative of $\mathbf{5}$, while it photoisomerizes to the correspondingly substituted $\mathbf{6}$, cannot be regenerated thermally even at temperatures as high as $275{ }^{\circ} \mathrm{C}$ (phenyloctane solvent). ${ }^{20}$

In conclusion, we have investigated the detailed mechanism of the thermal reversal reaction of the photoisomer $\mathbf{2}$ of $\mathrm{FvRu}_{2}(\mathrm{CO})_{4}(\mathbf{1})$, a representative of a promising platform for storing solar energy using organometallic molecules. In contrast to earlier suggestions, our first-principles calculations predict the existence of a diradical intermediate $\mathbf{B}$ with a surprisingly low barrier for $\mathrm{Cp}-\mathrm{Cp}$ bond rupture to furnish 2 and an equally unexpected high barrier to rotation to (re)generate 1. The new mechanism revealed by the calculations is consistent with all experimental findings. An extension to the $\mathrm{Fe}$ and Os relatives of this system reveals quantitatively very different thermodynamic and kinetic aspects, also corroborated by preliminary experiments. These results may be of relevance to other topologically related rearrangements. ${ }^{23}$ Our results indicate substantial promise for $\mathrm{FvRu}_{2}(\mathrm{CO})_{4}$ in solar-thermal energy storage applications from both energetic and kinetic standpoints. The understanding of the underlying reaction mechanisms will aid considerably in the further development of this platform. We are currently constructing a proof-of-principle device, based on derivatives of $\mathbf{1}$, to demonstrate the potential of the concept, together with computational work providing guidance to experiments aiming to increase the amount and efficiency of energy storage, in particular by tailoring the Fv frame through substitution and scanning the potential of other metals.

ACKNOWLEDGMENT This study was enabled by the Sustainable Products and Solutions Program at UC Berkeley and the NSF (CHE-0907800). Part of this work was performed under the auspices of the U.S. Department of Energy at Lawrence Livermore National Laboratory under Contract DE-AC52-07NA27344. J.C.G is grateful for support for this work from the MIT Energy Initiative seed fund program. All calculations were performed at the National Energy Research Scientific Computing Center of the Lawrence Berkeley National Laboratory and at Lawrence Livermore National Laboratory. We thank Mr. Dusan Coso for performing the DSC experiments and Professors A. Majumdar and R. A. Segalman for valuable discussions.

Supporting Information Available: Structural and analytical details of the computations. This material is available free of charge via the Internet at http://pubs.acs.org.

\section{REFERENCES}

\footnotetext{
'Lawrence Livermore National Laboratory, Livermore, CA 94554

Massachusetts Institute of Technology, Boston, MA 02139

${ }^{\S}$ University of California at Berkeley, Berkeley, CA 94720
}

(1) For some illustrative reviews, see: (a) Acc. Chem. Res. Special Issue Artificial Photosynthesis and Solar Fuels, 2009, 42, 1861-2029. (b) Carroll, A.;
Somerville, C. Annu. Rev. Plant Biol. 2009, 60, 165-182. (c) Balzani, V.; Credi, A.; Venturi, M. ChemSusChem 2008, 1, 26-58. (d)Arunachalam, V. S.; Fleischer, E. S. MRS Bull. 2008, 33, 265-275. (e) Lewis, N.; Nocera, D. G. Proc. Nat. Acad. Sci. 2006, 103, 15729-15735.

(2) See, inter alia: (a) Schnatbaum, L. Eur. Phys. J. Special Topics 2009, 176, 127-140. (b) Kenisarin, M.; Mahkamov, K. Renew. Sustain. Energ. Rev. 2007 $11,1913-1965$

(3) For a review of the problems of energy storage, see: H.; Chen, T. N.; Cong, W.; Yang, C.; Tan, Y.; Li, Y. Ding, Prog. Nat. Sci. 2009, 19, 291-312.

(4) For recent work, see: Vesally, E. Russ. J. Phys. Chem. A 2009, 83, 809-812 and the references therein.

(5) For selected general reviews, see: (a) Balzani, V.; Credi, A.; Venturi, M. Chem. Soc. Rev. 2009, 38, 1542-1550; b) Kay, E. R.; Leigh, D. A.; Zerbetto, F. Angew. Chem. Int. Ed. 2007, 46, 72-191; c) Photochromism, Molecules and Systems; Dürr, H., Bouas-Laurent, H., Eds.; Elsevier: Amsterdam, 2003.

(6) For a recent review, see: (a) Wang, M.-S.; Xu, G.; Zhang, Z.-J.; Guo, G.-C. Chem Commun. 2010, 46, 361-376. For some recent examples, see: (b) Albright, T. A.; Dosa, P. I.; Grossmann, T. N.; Khrustalev, V. N.; Oloba, O. A.; Padilla, R.; Paubelle, R.; Stanger, A.; Timofeeva, T. V.; Vollhardt, K. P. C. Angew. Chem. Int. Ed. 2009, 48, 9853-9857. (c) Ben-Asuly, A.; Aharoni, A. Diesendruck, C. E.; Vidavsky, Y.; Goldberg, I.; Straub, B. F.; Lemcoff, N. G. Organometallics 2009, 28, 4652-4655. (d) Zhu, G.; Pang, K.; Parkin, G. J. Am. Chem. Soc. 2008, 130, 1564-1565. (e) Tsuchiya, K.; Ideta, K.; Mogi, K.; Sunada, Y.; Nagashima, H. Dalton Trans. 2008, 2708-2716. (f) Nakai, H Nonaka, T.; Miyano, Y.; Mizuno, M.; Ozawa, Y.; Toriumi, K.; Koga, N.; Nishioka, T.; Irie, M.; Isobe, K. J. Am. Chem. Soc. 2008, 130, 17836-17845. (g) Miyazaki, S.; Kojima, T.; Fukuzumi, S. J. Am. Chem. Soc. 2008, 130, 1556-1557. (h) Jahr, H. C.; Nieger, M.; Dötz, K. H. Chem. Eur. J. 2005, 11 $5333-5342$.

(7) Boese, R.; Cammack, J. K.; Matzger, A. J.; Pflug, K.; Tolman, W. B.; Vollhardt, K. P. C.; Weidman, T. W. J. Am. Chem. Soc. 1997, 119, 6757-6773. The originally reported $\Delta H$ for the thermal reverse reaction $(2 \rightarrow \mathbf{1})$ is in error The new measurement is based on an average of 6 runs (TA Instruments DSC 2920 and Q20).

(8) Perdew, J. P.; Burke, K.; Ernzerhof, M. Phys. Rev. Lett. 1996, 77, 3865 3868.

(9) Vanderbilt, D. Phys. Rev. B 1990, 41, 7892-7895.

(10) E, W ; Ren, W ; Vanden-Eijnden, E. Phys, Rev. B. 2002, 66, 052301, 1-4. (11) (a) Kanai, Y.; Tilocca, A.: Selloni, A.; Car, R. J. Chem. Phys. 2004, 121, 3359-3367. (b) Car, R.; Parrinello, M; Phys. Rev. Lett. 1985, 55, 2471-2474.

(12) We emphasize that the excellent agreement (i.e., within $1 \mathrm{kcal} \mathrm{mol}^{-1}$ ) of some of the experimental values with those computed by DFT calculations is fortuitous, albeit gratifying.

(13) Geiger, W. E.; Salzer, A.; Edwin, J.; von Philipsborn, W.; Piantini, U.; Rheingold, A. L. J. Am. Chem. Soc. 1990, 112, 7113-7121.

(14) (a) NIST Chemistry Webbook, See also (b) Elihn, K.; Larsson, K. Thin Solid Films 2004, 458, 325-329.

(15) (a) Simões, J. A. M.; Beauchamp, J. L. Chem. Rev. 1990, 90, 629-688. (b) Compare TpRu ${ }^{\text {II }}(\mathrm{CO})\left(\mathrm{CH}_{3} \mathrm{CN}\right)-\mathrm{CH}_{3}, 48.6 \mathrm{kcal} \mathrm{mol}^{-1}$ : Lail, M.; Gunnoe, T. B. Barakat, K. A.; Cundari, T. R. Organometallics 2005, 24, 1301-1305, and the typical correction increment for Ph, 12-15 kcal mol ${ }^{-1}$.

(16) (a) Hamon, P.; Toupet, L.; Hamon, J.-R.; Lapinte, C. Organometallics 1996, 15, 10-12. (b) See also: Costuas, K.; Saillard, J.Y. Organometallics 1999, 18, 2505-2512.

(17) See, e.g., Sun, X. Z.; Nikiforov, S. M.; Dedieu, A.; George, M. W. Organometallics 2001, 20, 1515-1520.

(18) This barrier in $\mathrm{FvRh}_{2}(\mathrm{CO})_{4}$, in which the metal is pseudotrigonal, has been estimated to be $<5 \mathrm{kcal} \mathrm{mol}^{-1}$ : Chin, T. T.; Geiger, W. E.; Rheingold, A L. J. Am. Chem. Soc. 1996, 118, 5002-5010.

(19)Hu, S.-Z.; Zhou, Z.-H.; Robertson, B. E. Z. Kristallogr. 2009, 224, 375 383 .

(20)Zhu, B.; Miljanić, O. Š.; Vollhardt, K. P. C.; West, M. J. Synthesis 2005 , 3373-3379.

(21)(a) Cutler, A. R.; Rosenblum, M. J. Organomet. Chem. 1976, 120, 87-96. (b) FvM-M bond strengths appear to be comparable to, if not stronger than those in their CpM-MCp analogs. See: Vollhardt, K. P. C.; Cammack, J. K.; Matzger, A. J.; Bauer, A.; Capps, K. B.; Hoff, C. D. Inorg. Chem. 1999, 38 2624-2631.

(22)The DFT-calculated Os-Os bond dissociation energy for $\left[\mathrm{CpOs}(\mathrm{CO})_{2}\right]$ is 52.8 (BP86) and $54.6 \mathrm{kcal} \mathrm{mol}^{-1}$ (MPW1PW91): Xu, B.; Li, Q.-S.; Xie, Y.; King, R. B.; Schaefer, H. F., III Organometallics 2008, 27, 5921-5928.

(23) See, inter alia: (a) González-Maupoey, M.; Tebernero, V.; Cuenca, T Coord. Chem. Rev. 2009, 253, 1854-1881. (b) Berry, M.; Cooper, N. J.; Green, M. L. H.; Simpson, S. J. J. Chem. Soc., Dalton Trans. 1980, 29-40. 


\section{Table of Contents artwork Idea}

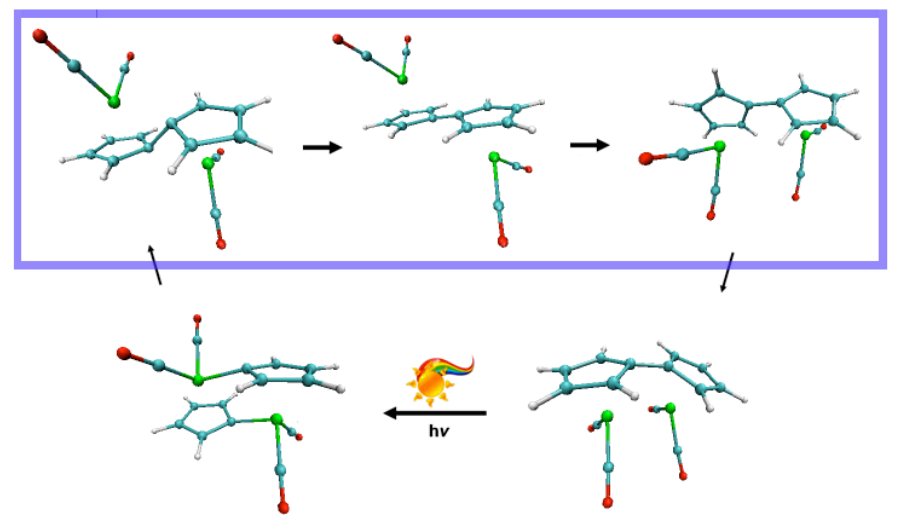

ABSTRACT FOR WEB PUBLICATION (Word Style "BD_Abstract"). Authors are required to submit a concise, selfcontained, one-paragraph abstract for Web publication.

In the currently intensifying quest to harness solar energy for the powering of our planet, most efforts are centered around photoinduced generic charge separation, such as in photovoltaics, water splitting, other small molecule activation. In contrast, an attractive alternative strategy would be to trap solar energy in the form of chemical bonds, ideally through the photoconversion of a suitable molecule to a higher energy isomer, which, in turn, would release the stored energy by thermal reversal. A highly promising organometallic system is the previously reported, robust photo-thermal fulvalene diruthenium. In this communication, we present a theoretical investigation, in conjunction with corroborating experiments, of the mechanism for the heat releasing step and its $\mathrm{Fe}$ and Os relatives. The results of the combined study has enabled a rigorous interpretation of earlier and new experimental measurements and paint a surprising picture. The understanding of the underlying reaction mechanisms is of significant interest for improving the solar-thermal energy storage cycle. 
Mechanism of Thermal Reversal of the (Fulvalene)tetracarbonyldiruthenium Photoisomerization: Toward Molecular Solar-Thermal Energy Storage

Yosuke Kanai, Varadharajan Srinivasan, Steven K. Meier, K. Peter C. Vollhardt, Jeffrey C. Grossman

\section{Supporting Information}

1. Structural Evolution of 2 to $\mathrm{FvRu}_{2}(\mathrm{CO})_{4} 1$ along the Minimum Energy Path
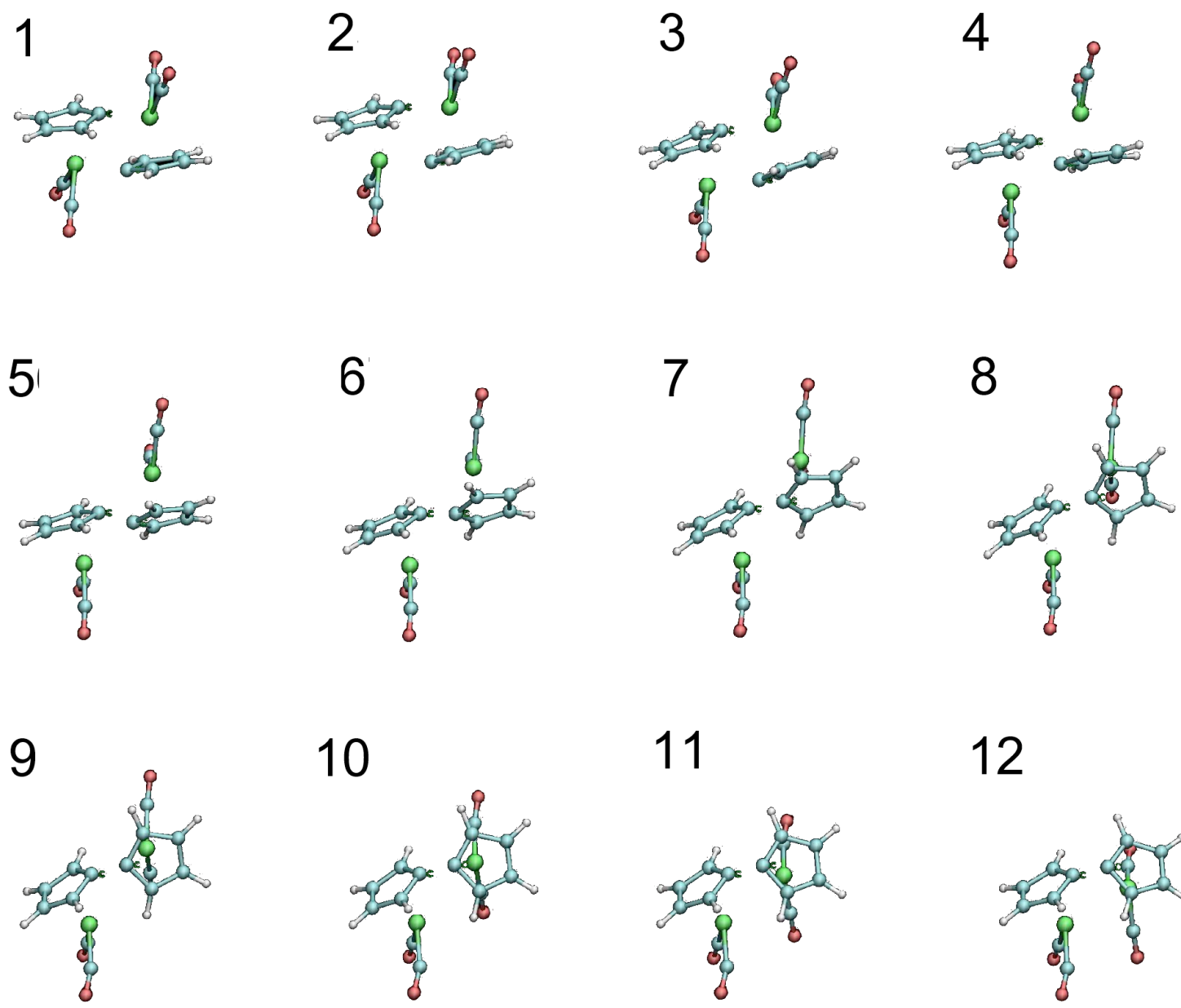

12

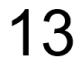

14
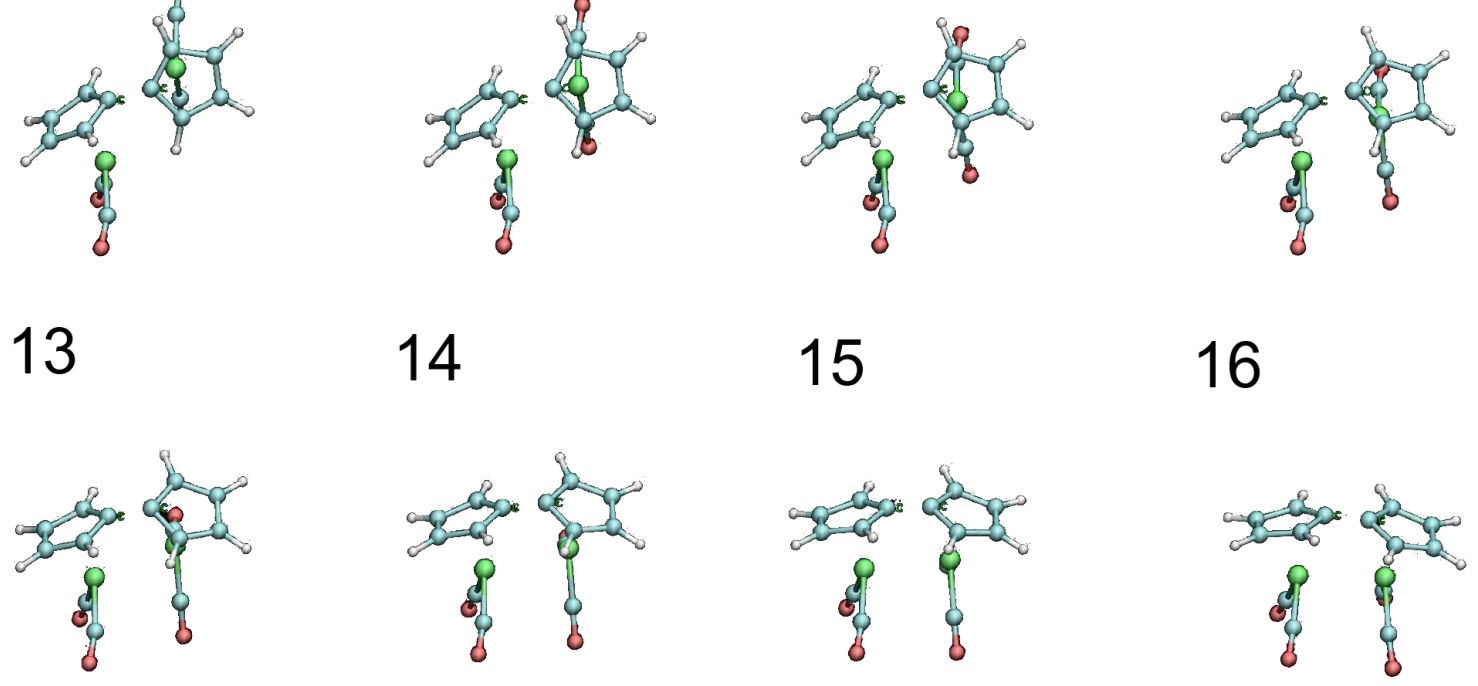
2. Key Geometrical Parameters in Angstrom and Degree and Structures in Cartesian Coordinates (see Figure $1 ; \mathrm{m}=\mathrm{Ru}, \mathrm{Fe}$, or Os)

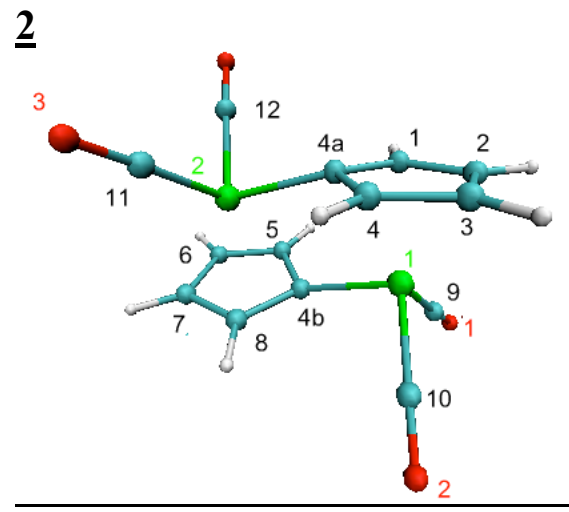

4a-4b m1-m2 4a-m1 4a-m2 4b-m2 4b-m1 m1-11 m1-12 m2-9 m2-10

$\begin{array}{lllllllllll}\mathrm{Ru} & 2.65 & 3.54 & 2.32 & 2.11 & 2.31 & 2.14 & 4.69 & 4.85 & 4.82 & 4.76 \\ \mathrm{Fe} & 2.32 & 3.38 & 2.12 & 1.98 & 2.12 & 1.98 & 4.49 & 4.50 & 4.51 & 4.48 \\ \mathrm{Os} & 2.63 & 3.50 & 2.30 & 2.07 & 2.30 & 2.07 & 4.71 & 4.70 & 4.68 & 4.73\end{array}$

9-m1-10 11-m2-12 4a-m1-4b 4a-m2-4b

$\begin{array}{lllll}\mathrm{Ru} & 91.1 & 91.3 & 72.6 & 73.2 \\ \mathrm{Fe} & 91.0 & 90.7 & 69.0 & 69.0 \\ \mathrm{Os} & 91.6 & 91.8 & 73.8 & 73.9\end{array}$
C $\quad-0.0906999 \quad 5.81253 \quad 0.200934$
C $0.536609 \quad 3.59165-0.272443$
C $\quad-0.572199 \quad 4.49177 \quad-0.131953$
C $1.72609 \quad 4.37984 \quad 0.0145205$
C $1.32989 \quad 5.74555 \quad 0.287692$
C $-0.985882 \quad 4.63516 \quad 3.11932$
C $1.73266 \quad 4.53541 \quad 3.30257$
C $1.07623 \quad 0.0540703 \quad 1.40958$
C $\quad 0.525194 \quad 2.26784 \quad 2.01399$
C $1.61421 \quad 1.3775 \quad 1.63991$
C $-\begin{array}{llll}-0.671391 & 1.47517 & 1.96938\end{array}$
C $\quad-0.336804 \quad 0.115573 \quad 1.606$
C $1.3655 \quad 1.21296-1.62849$
$\begin{array}{llll}\text { C } & -1.33907 & 1.31134 & -1.27431\end{array}$
$\begin{array}{llll}\mathrm{H} & -0.705149 & 6.7002 & 0.333671\end{array}$
$\begin{array}{llll}\mathrm{H} & -1.61443 & 4.21777 & -0.27879\end{array}$
H $2.75695 \quad 4.02592 \quad-0.00220345$ 


\begin{tabular}{lccl}
$\mathrm{H}$ & 1.99881 & 6.57744 & 0.505426 \\
$\mathrm{H}$ & 1.64965 & -0.834133 & 1.14482 \\
$\mathrm{H}$ & 2.67121 & 1.64406 & 1.57358 \\
$\mathrm{H}$ & -1.67239 & 1.83867 & 2.19823 \\
$\mathrm{H}$ & -1.03884 & -0.713316 & 1.52854 \\
$\mathrm{O}$ & -1.88635 & 4.81548 & 3.83883 \\
$\mathrm{O}$ & 2.53962 & 4.63632 & 4.1364 \\
$\mathrm{O}$ & 2.10896 & 1.05044 & -2.51028 \\
$\mathrm{O}$ & -2.29097 & 1.17338 & -1.93798 \\
$\mathrm{Ru}$ & 0.458135 & 4.37637 & 1.89798 \\
$\mathrm{Ru}$ & 0.208837 & 1.48186 & -0.144533 \\
& \multicolumn{4}{|c}{} \\
$\mathrm{C}$ & -0.445249 & 5.684873 & 0.861902 \\
$\mathrm{C}$ & -0.036111 & 3.470678 & 0.162106 \\
$\mathrm{C}$ & -0.963195 & 4.339305 & 0.849985 \\
$\mathrm{C}$ & 1.068378 & 4.315953 & -0.227919 \\
$\mathrm{C}$ & 0.811540 & 5.670321 & 0.195052 \\
$\mathrm{C}$ & 0.340358 & 4.626824 & 3.504905 \\
$\mathrm{C}$ & 2.537645 & 4.625443 & 2.327364 \\
$\mathrm{C}$ & 1.328693 & 0.184812 & 1.284999 \\
$\mathrm{C}$ & 0.925270 & 2.399595 & 1.986266 \\
$\mathrm{C}$ & 1.848576 & 1.530037 & 1.294382 \\
$\mathrm{C}$ & -0.178302 & 1.555178 & 2.380757 \\
$\mathrm{C}$ & 0.074720 & 0.200464 & 1.957035 \\
$\mathrm{C}$ & 0.540420 & 1.217985 & -1.348653 \\
$\mathrm{C}$ & -1.663536 & 1.274575 & -0.168323 \\
$\mathrm{H}$ & -0.929651 & 6.554670 & 1.302975 \\
$\mathrm{H}$ & -1.902594 & 4.027148 & 1.303494 \\
$\mathrm{H}$ & 1.964687 & 3.982872 & -0.748813 \\
$\mathrm{H}$ & 1.464277 & 6.526730 & 0.032502 \\
$\mathrm{H}$ & 1.810529 & -0.685370 & 0.841624 \\
$\mathrm{H}$ & 2.786683 & 1.840575 & 0.836993 \\
$\mathrm{H}$ & -1.072236 & 1.889809 & 2.904662 \\
$\mathrm{H}$ & -0.578298 & -0.655255 & 2.121839 \\
$\mathrm{O}$ & 0.012123 & 4.779654 & 4.616013 \\
$\mathrm{O}$ & 3.645394 & 4.787406 & 2.662799 \\
$\mathrm{O}$ & 0.872739 & 1.037390 & -2.454518 \\
$\mathrm{O}$ & -2.778222 & 1.145849 & -0.495929 \\
$\mathrm{Fe}$ & 0.870077 & 4.373341 & 1.853450 \\
$\mathrm{Fe}$ & 0.011874 & 1.497705 & 0.298829 \\
& & & \\
$\mathrm{C}$ & -0.099462 & 5.783616 & 0.226381 \\
$\mathrm{C}$ & 0.511732 & 3.548524 & -0.270521 \\
$\mathrm{C}$ & -0.598057 & 4.461104 & -0.104688 \\
$\mathrm{C}$ & 1.695847 & 4.322552 & 0.033707 \\
$\mathrm{C}$ & 1.323454 & 5.697891 & 0.310934
\end{tabular}




$\begin{array}{lccc}\mathrm{H} & -0.703849 & 6.692307 & 0.337814 \\ \mathrm{H} & -1.656397 & 4.213114 & -0.253834 \\ \mathrm{H} & 2.725802 & 3.945084 & 0.000072 \\ \mathrm{H} & 2.007369 & 6.535355 & 0.497038 \\ \mathrm{Os} & 0.433991 & 4.369674 & 1.880046 \\ \mathrm{C} & -0.975567 & 4.666766 & 3.073102 \\ \mathrm{O} & -1.875622 & 4.844959 & 3.790593 \\ \mathrm{C} & 1.703366 & 4.522705 & 3.247246 \\ \mathrm{O} & 2.508160 & 4.616812 & 4.083986 \\ \mathrm{C} & 0.908728 & 0.076951 & 1.555501 \\ \mathrm{C} & 0.299353 & 2.312198 & 2.044771 \\ \mathrm{C} & 1.407164 & 1.398210 & 1.888703 \\ \mathrm{C} & -0.885116 & 1.541515 & 1.733355 \\ \mathrm{C} & -0.512832 & 0.165653 & 1.460832 \\ \mathrm{H} & 1.512140 & -0.833104 & 1.453228 \\ \mathrm{H} & 2.462762 & 1.646036 & 2.054614 \\ \mathrm{H} & -1.914378 & 1.921205 & 1.760337 \\ \mathrm{H} & -1.199396 & -0.666511 & 1.263409 \\ \mathrm{Os} & 0.389972 & 1.490418 & -0.104112 \\ \mathrm{C} & 1.819921 & 1.203079 & -1.274771 \\ \mathrm{O} & 2.734063 & 1.032109 & -1.976302 \\ \mathrm{C} & -0.852366 & 1.309151 & -1.493783 \\ \mathrm{O} & -1.636569 & 1.185060 & -2.346461\end{array}$

$\underline{\mathbf{C}}$

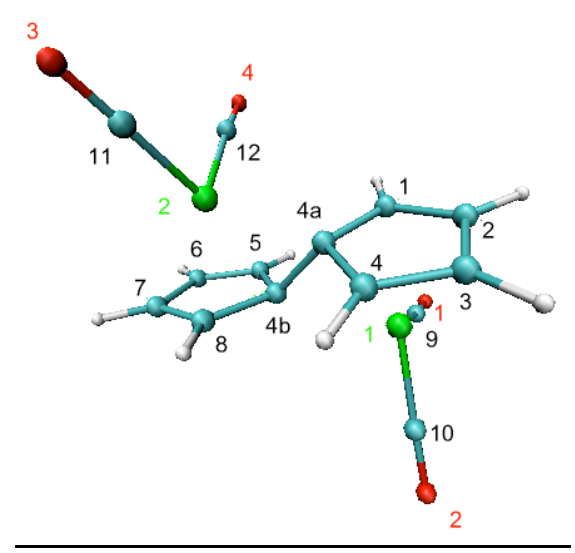

$\underline{\text { 4a-4b m1-m2 }}$ 4a-m1 4a-m2 4b-m2 4b-m1 m1-11 m1-12 m2-9 m2-10

$\begin{array}{lllllllllll}\mathrm{Ru} & 1.54 & 4.32 & 2.21 & 2.39 & 2.21 & 2.43 & 5.28 & 5.76 & 5.83 & 5.31 \\ \mathrm{Fe} & 1.48 & 4.26 & 2.03 & 2.51 & 2.03 & 2.47 & 5.62 & 5.11 & 5.55 & 5.13 \\ & & & & & & & & & & \\ & \end{array}$




$\begin{array}{cccc}\mathrm{Ru} & 91.3 & 90.6 & 38.3 \\ \mathrm{Fe} & 89.1 & 90.0 & 36.7 \\ & & & \\ \mathrm{C} & -0.133723 & 6.088711 & 0.221302 \\ \mathrm{C} & 0.546322 & 3.898870 & -0.325656 \\ \mathrm{C} & -0.599028 & 4.761905 & -0.025136 \\ \mathrm{C} & 1.723688 & 4.790322 & -0.246967 \\ \mathrm{C} & 1.293626 & 6.098447 & 0.099538 \\ \mathrm{C} & -0.725237 & 4.429582 & 3.018161 \\ \mathrm{C} & 1.972507 & 4.537587 & 3.198928 \\ \mathrm{C} & 1.405177 & 0.423765 & -0.260726 \\ \mathrm{C} & 0.764555 & 2.586511 & 0.440963 \\ \mathrm{C} & 1.851008 & 1.766922 & -0.140708 \\ \mathrm{C} & -0.334546 & 1.644523 & 0.669991 \\ \mathrm{C} & 0.069746 & 0.341478 & 0.253846 \\ \mathrm{C} & 0.612946 & 1.774807 & -3.340641 \\ \mathrm{C} & -1.777876 & 1.804758 & -2.026113 \\ \mathrm{H} & -0.759104 & 6.950793 & 0.445937 \\ \mathrm{H} & -1.637962 & 4.438684 & -0.014235 \\ \mathrm{H} & 2.755583 & 4.478002 & -0.393231 \\ \mathrm{H} & 1.940227 & 6.961429 & 0.248025 \\ \mathrm{H} & 1.980498 & -0.404291 & -0.670891 \\ \mathrm{H} & 2.818450 & 2.145919 & -0.462712 \\ \mathrm{H} & -1.293309 & 1.902285 & 1.115346 \\ \mathrm{H} & -0.527219 & -0.565320 & 0.334757 \\ \mathrm{O} & -1.702468 & 4.407780 & 3.658677 \\ \mathrm{O} & 2.709862 & 4.533406 & 4.103609 \\ \mathrm{O} & 0.911507 & 1.671035 & -4.464402 \\ \mathrm{O} & -2.933704 & 1.705961 & -2.171901 \\ \mathrm{Ru} & 0.701742 & 4.565104 & 1.773378 \\ \mathrm{Ru} & 0.054981 & 1.836720 & -1.513182 \\ & & & \\ \mathrm{C} & -0.179444 & 6.101093 & 0.358729 \\ \mathrm{C} & 0.552884 & 3.979464 & -0.311632 \\ \mathrm{C} & -0.609612 & 4.768890 & 0.064613 \\ \mathrm{C} & 1.697706 & 4.886897 & -0.226858 \\ \mathrm{C} & 1.234993 & 6.165494 & 0.191297 \\ \mathrm{C} & -0.511608 & 4.415876 & 2.822789 \\ \mathrm{C} & 1.946789 & 4.574629 & 2.878670 \\ \mathrm{C} & 1.412850 & 0.496527 & -0.643691 \\ \mathrm{C} & 0.776250 & 2.602175 & 0.168278 \\ \mathrm{C} & 1.840954 & 1.844711 & -0.491447 \\ \mathrm{C} & -0.298985 & 1.651508 & 0.405614 \\ \mathrm{C} & 0.107423 & 0.370530 & -0.083557\end{array}$




$\begin{array}{lrrr}\mathrm{C} & 0.490547 & 1.880801 & -3.306351 \\ \mathrm{C} & -1.631982 & 1.871540 & -2.012619 \\ \mathrm{H} & -0.824246 & 6.926504 & 0.654804 \\ \mathrm{H} & -1.632617 & 4.402382 & 0.118006 \\ \mathrm{H} & 2.735792 & 4.608073 & -0.394819 \\ \mathrm{H} & 1.858470 & 7.042129 & 0.358676 \\ \mathrm{H} & 1.983937 & -0.299461 & -1.118733 \\ \mathrm{H} & 2.774634 & 2.263025 & -0.861818 \\ \mathrm{H} & -1.253144 & 1.881965 & 0.874571 \\ \mathrm{H} & -0.478270 & -0.545370 & -0.032333 \\ \mathrm{O} & -1.394911 & 4.302262 & 3.582793 \\ \mathrm{O} & 2.672291 & 4.519965 & 3.795257 \\ \mathrm{O} & 0.671896 & 1.850691 & -4.462232 \\ \mathrm{O} & -2.787228 & 1.850691 & -2.205398 \\ \mathrm{Fe} & 0.728994 & 4.610084 & 1.605100 \\ \mathrm{Fe} & 0.069005 & 1.878578 & -1.594304\end{array}$

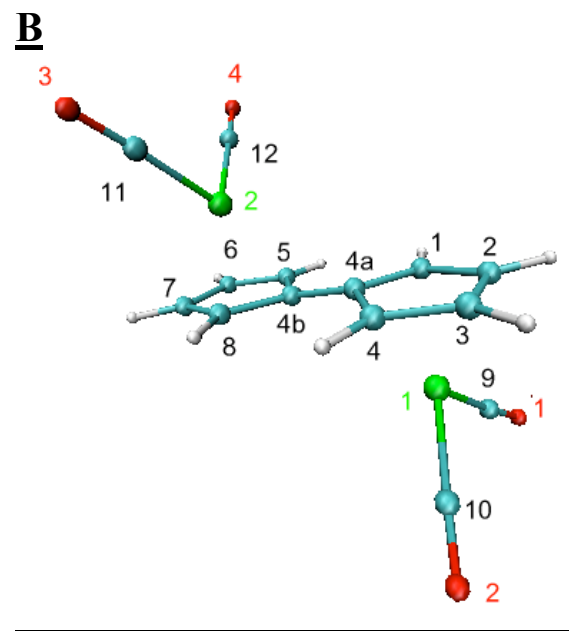

$\underline{\text { 4a-4b m1-m2 4a-m1 4a-m2 4b-m2 4b-m1 m1-11 m1-12 m2-9 m2-10 }}$

\begin{tabular}{|c|c|c|c|c|c|c|c|c|c|c|}
\hline $\mathrm{Ru}$ & 1.43 & 6.81 & 2.32 & 3.27 & 2.33 & 3.25 & 6.86 & 6.83 & 6.81 & 6.86 \\
\hline $\mathrm{Fe}$ & 1.46 & 5.29 & 2.16 & 3.23 & 2.16 & 3.23 & 6.48 & 6.56 & 6.53 & 6.51 \\
\hline Os & 1.47 & 5.46 & 2.25 & 3.31 & 2.25 & 3.30 & 6.79 & 6.80 & 6.74 & 6.85 \\
\hline & \multicolumn{2}{|c|}{ 9-m1-10 } & \multicolumn{2}{|c|}{$11-\mathrm{m} 2-12$} & \multicolumn{2}{|c|}{$4 a-m 1-4 b$} & \multicolumn{2}{|c|}{$4 a-m 2-4 b$} & & \\
\hline $\mathrm{Ru}$ & \multicolumn{2}{|l|}{91.2} & \multicolumn{2}{|l|}{91.1} & \multicolumn{2}{|l|}{22.8} & \multicolumn{2}{|l|}{22.5} & & \\
\hline $\mathrm{Fe}$ & \multicolumn{2}{|l|}{93.6} & \multicolumn{2}{|l|}{93.5} & \multicolumn{2}{|l|}{21.9} & \multicolumn{2}{|l|}{21.8} & & \\
\hline Os & \multicolumn{2}{|l|}{94.3} & \multicolumn{2}{|l|}{94.3} & \multicolumn{2}{|l|}{21.7} & \multicolumn{2}{|c|}{21.6} & & \\
\hline & \multicolumn{2}{|c|}{-0.302136797} & \multicolumn{3}{|c|}{6.108340190} & \multicolumn{3}{|c|}{0.730066255} & & \\
\hline
\end{tabular}




$\begin{array}{lrrr}\mathrm{C} & 0.418734912 & 4.068807301 & -0.169585764 \\ \mathrm{C} & -0.678027339 & 4.747995958 & 0.498260657 \\ \mathrm{C} & 1.500562448 & 5.033396185 & -0.256063909 \\ \mathrm{C} & 1.046021195 & 6.284725785 & 0.266092560 \\ \mathrm{C} & 0.205129817 & 4.797731243 & 3.662966143 \\ \mathrm{C} & 2.774220640 & 5.034491466 & 2.762850880 \\ \mathrm{C} & 1.231252149 & 0.661001758 & -1.430850057 \\ \mathrm{C} & 0.505480021 & 2.676086311 & -0.478946395 \\ \mathrm{C} & 1.590476301 & 2.024319255 & -1.190539627 \\ \mathrm{C} & -0.555852529 & 1.690237977 & -0.365664141 \\ \mathrm{C} & -0.094558729 & 0.454813140 & -0.918443787 \\ \mathrm{C} & 0.612730472 & 2.141567494 & -4.307467046 \\ \mathrm{C} & -1.898811882 & 1.619192171 & -3.367846718 \\ \mathrm{H} & -0.933480513 & 6.879514960 & 1.166840193 \\ \mathrm{H} & -1.648378175 & 4.312100247 & 0.728695849 \\ \mathrm{H} & 2.481311141 & 4.849576940 & -0.690495772 \\ \mathrm{H} & 1.615206478 & 7.211864869 & 0.286143189 \\ \mathrm{H} & 1.860115169 & -0.092525044 & -1.900593303 \\ \mathrm{H} & 2.538466806 & 2.485112431 & -1.461510700 \\ \mathrm{H} & -1.521466090 & 1.849127836 & 0.110257260 \\ \mathrm{H} & -0.646438916 & -0.483051336 & -0.935525747 \\ \mathrm{O} & -0.355302770 & 4.879271393 & 4.683447045 \\ \mathrm{O} & 3.825051586 & 5.240940961 & 3.228041272 \\ \mathrm{O} & 1.146615485 & 2.197863115 & -5.343441586 \\ \mathrm{O} & -2.936203256 & 1.322008623 & -3.814108297 \\ \mathrm{Ru} & 1.058988979 & 4.791687464 & 1.950926496 \\ \mathrm{Ru} & -0.193699605 & 1.975908308 & -2.580592951 \\ \mathrm{C} & -0.188229730 & 6.140731900 & 0.762115553 \\ \mathrm{C} & 0.482505324 & 4.073703235 & -0.104127353 \\ \mathrm{C} & -0.598924982 & 4.773645817 & 0.530285702 \\ \mathrm{C} & 1.583337330 & 4.991726048 & -0.185480637 \\ \mathrm{C} & 1.152478710 & 6.275121263 & 0.321338533 \\ \mathrm{C} & 0.202242600 & 4.845234653 & 3.388328023 \\ \mathrm{C} & 2.625433345 & 5.039959728 & 2.583500718 \\ \mathrm{C} & 1.145923012 & 0.620748916 & -1.436741688 \\ \mathrm{C} & 0.491872268 & 2.669053409 & -0.514559517 \\ \mathrm{C} & 1.538081545 & 1.997677587 & -1.232816853 \\ \mathrm{C} & -0.575801614 & 1.722832906 & -0.350634133 \\ \mathrm{C} & -0.152399677 & 0.451667109 & -0.893249962 \\ \mathrm{C} & 0.520963442 & 1.915316084 & -4.017918099 \\ \mathrm{C} & -1.828485444 & 1.645270137 & -3.031298433 \\ \mathrm{H} & -0.802243005 & 6.918436893 & 1.212076766 \\ \mathrm{H} & -1.582603575 & 4.363943062 & 0.752173225 \\ \mathrm{H} & 2.566682893 & 4.773813453 & -0.598337001 \\ \mathrm{H} & 1.763146888 & 7.174476190 & 0.370622597\end{array}$




\begin{tabular}{lrrr}
$\mathrm{H}$ & 1.742151145 & -0.140042990 & -1.936750498 \\
$\mathrm{H}$ & 2.487166421 & 2.435239484 & -1.537136970 \\
$\mathrm{H}$ & -1.525776206 & 1.911999550 & 0.145917391 \\
$\mathrm{H}$ & -0.741215848 & -0.463470647 & -0.896566017 \\
$\mathrm{O}$ & -0.379694985 & 4.925257619 & 4.400116385 \\
$\mathrm{O}$ & 3.676570350 & 5.250414594 & 3.052838423 \\
$\mathrm{O}$ & 1.028661748 & 1.855895786 & -5.070220518 \\
$\mathrm{O}$ & -2.905883935 & 1.403701623 & -3.419217437 \\
$\mathrm{Fe}$ & 1.047763321 & 4.795746590 & 1.847902068 \\
$\mathrm{Fe}$ & -0.207241339 & 1.935160000 & -2.417740267 \\
& \multicolumn{3}{|c}{} \\
$\mathrm{C}$ & -0.224850 & 6.140806 & 0.707326 \\
$\mathrm{C}$ & 0.484914 & 4.077519 & -0.103009 \\
$\mathrm{C}$ & -0.638687 & 4.783517 & 0.455412 \\
$\mathrm{C}$ & 1.572624 & 5.005731 & -0.244866 \\
$\mathrm{C}$ & 1.140308 & 6.278443 & 0.276716 \\
$\mathrm{C}$ & 0.131357 & 4.871899 & 3.595864 \\
$\mathrm{C}$ & 2.757298 & 5.074301 & 2.726564 \\
$\mathrm{C}$ & 1.186865 & 0.618907 & -1.388447 \\
$\mathrm{C}$ & 0.499826 & 2.664858 & -0.515647 \\
$\mathrm{C}$ & 1.587775 & 1.985954 & -1.168640 \\
$\mathrm{C}$ & -0.551035 & 1.710902 & -0.285148 \\
$\mathrm{C}$ & -0.134872 & 0.450013 & -0.847185 \\
$\mathrm{C}$ & 0.570726 & 1.888550 & -4.228275 \\
$\mathrm{C}$ & -1.971672 & 1.609809 & -3.159166 \\
$\mathrm{H}$ & -0.838401 & 6.930539 & 1.135392 \\
$\mathrm{H}$ & -1.627621 & 4.371569 & 0.640904 \\
$\mathrm{H}$ & 2.549165 & 4.788115 & -0.670892 \\
$\mathrm{H}$ & 1.732899 & 7.189621 & 0.318730 \\
$\mathrm{H}$ & 1.780186 & -0.156081 & -1.868600 \\
$\mathrm{H}$ & 2.543725 & 2.423699 & -1.445465 \\
$\mathrm{H}$ & -1.490296 & 1.903832 & 0.227712 \\
$\mathrm{H}$ & -0.709321 & -0.473766 & -0.845037 \\
$\mathrm{O}$ & -0.501172 & 4.939654 & 4.581533 \\
$\mathrm{O}$ & 3.843319 & 5.282963 & 3.120537 \\
$\mathrm{O}$ & 1.129746 & 1.843644 & -5.258622 \\
$\mathrm{O}$ & -3.075308 & 1.366375 & -3.476716 \\
$\mathrm{Os}$ & 1.054302 & 4.798238 & 1.949272 \\
$\mathrm{Os}$ & -0.222474 & 1.932487 & -2.513748 \\
& & &
\end{tabular}




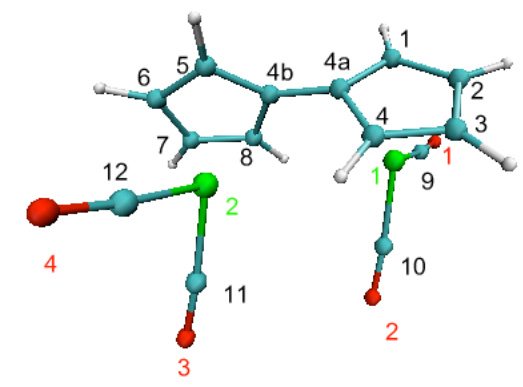

$\underline{4 a-4 b}$ m1-m2 4a-m1 4a-m2 4b-m2 4b-m1 m1-11 m1-12 m2-9 m2-10

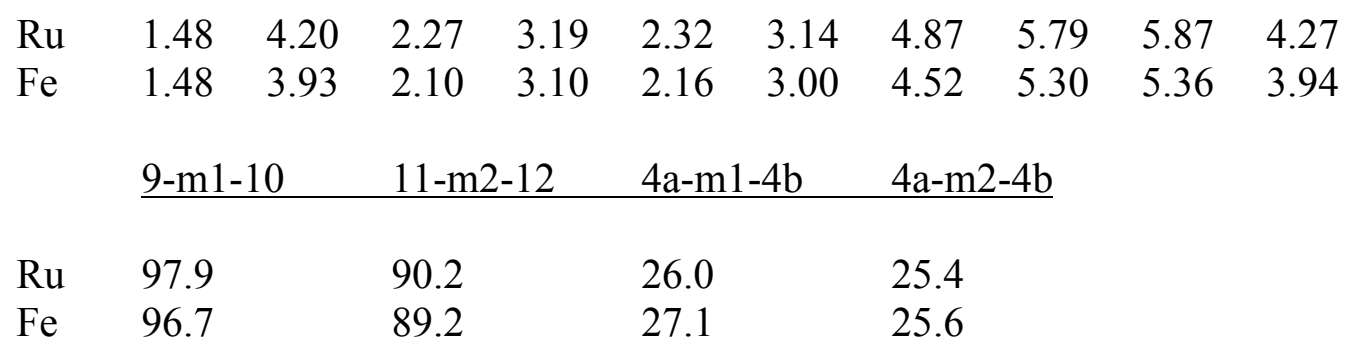

$\begin{array}{lrrr}\mathrm{C} & 0.152403 & 6.245664 & 0.195901 \\ \mathrm{C} & 1.304210 & 4.454242 & -0.772493 \\ \mathrm{C} & 0.008626 & 5.070997 & -0.617761 \\ \mathrm{C} & 2.241594 & 5.250018 & -0.028893 \\ \mathrm{C} & 1.529586 & 6.368434 & 0.548016 \\ \mathrm{C} & -0.786622 & 4.217382 & 2.608790 \\ \mathrm{C} & 1.885987 & 4.337558 & 2.994983 \\ \mathrm{C} & 1.381681 & 1.155405 & -2.628475 \\ \mathrm{C} & 1.474710 & 3.084890 & -1.315375 \\ \mathrm{C} & 1.490268 & 2.597359 & -2.674513 \\ \mathrm{C} & 1.339135 & 1.934195 & -0.458585 \\ \mathrm{C} & 1.277857 & 0.748680 & -1.266215 \\ \mathrm{C} & -1.580916 & 2.068341 & -3.362920 \\ \mathrm{C} & -1.920330 & 1.769991 & -0.508169 \\ \mathrm{H} & -0.654169 & 6.913645 & 0.491447 \\ \mathrm{H} & -0.911931 & 4.696869 & -1.068885 \\ \mathrm{H} & 3.311484 & 5.066923 & 0.048631 \\ \mathrm{H} & 1.967215 & 7.165427 & 1.145457 \\ \mathrm{H} & 1.380834 & 0.488483 & -3.488970 \\ \mathrm{H} & 1.599702 & 3.194853 & -3.577395 \\ \mathrm{H} & 1.303628 & 1.989917 & 0.632367 \\ \mathrm{H} & 1.181758 & -0.268557 & -0.893357 \\ \mathrm{O} & -1.693313 & 4.164464 & 3.339636 \\ \mathrm{O} & 2.612229 & 4.418363 & 3.905273 \\ \mathrm{O} & -2.082682 & 2.046327 & -4.416935\end{array}$




$\begin{array}{lrrr}\mathrm{O} & -2.718594 & 1.646270 & 0.332588 \\ \mathrm{Ru} & 0.741483 & 4.447256 & 1.479420 \\ \mathrm{Ru} & -0.515948 & 2.105331 & -1.776024 \\ & & & \\ \mathrm{C} & 0.130389 & 6.233546 & 0.257021 \\ \mathrm{C} & 1.256478 & 4.431857 & -0.717723 \\ \mathrm{C} & -0.026723 & 5.055704 & -0.560769 \\ \mathrm{C} & 2.195450 & 5.203292 & 0.041964 \\ \mathrm{C} & 1.499688 & 6.337053 & 0.612734 \\ \mathrm{C} & -0.683644 & 4.300621 & 2.431568 \\ \mathrm{C} & 1.759725 & 4.369838 & 2.767754 \\ \mathrm{C} & 1.214726 & 1.124872 & -2.546558 \\ \mathrm{C} & 1.430948 & 3.068856 & -1.270078 \\ \mathrm{C} & 1.265262 & 2.577886 & -2.610483 \\ \mathrm{C} & 1.440261 & 1.925093 & -0.402862 \\ \mathrm{C} & 1.322995 & 0.729153 & -1.192289 \\ \mathrm{C} & -1.545673 & 2.020345 & -2.800193 \\ \mathrm{C} & -1.554881 & 1.693631 & -0.187170 \\ \mathrm{H} & -0.672531 & 6.907136 & 0.549233 \\ \mathrm{H} & -0.954000 & 4.699092 & -1.010993 \\ \mathrm{H} & 3.257349 & 4.986911 & 0.144994 \\ \mathrm{H} & 1.947318 & 7.111186 & 1.232136 \\ \mathrm{H} & 1.102593 & 0.457050 & -3.399063 \\ \mathrm{H} & 1.211180 & 3.169664 & -3.522467 \\ \mathrm{H} & 1.539058 & 1.985260 & 0.682056 \\ \mathrm{H} & 1.308813 & -0.285967 & -0.801597 \\ \mathrm{O} & -1.544033 & 4.204523 & 3.217237 \\ \mathrm{O} & 2.455593 & 4.378410 & 3.709531 \\ \mathrm{O} & -2.226618 & 2.026695 & -3.752288 \\ \mathrm{O} & -2.323616 & 1.557474 & 0.683062 \\ \mathrm{Fe} & 0.710103 & 4.518801 & 1.373691 \\ \mathrm{Fe} & -0.392755 & 2.038072 & -1.474075 \\ & & & \end{array}$

1

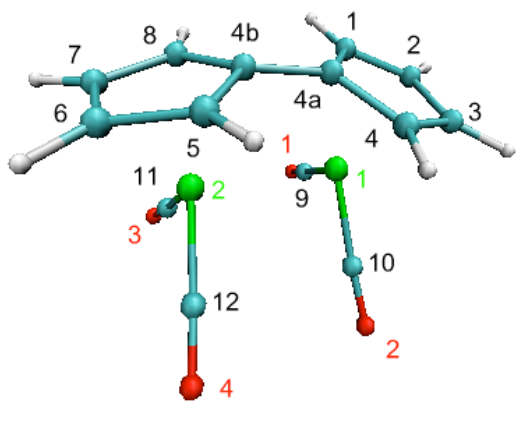


$\underline{\text { 4a-4b m1-m2 4a-m1 4a-m2 4b-m2 4b-m1 m1-11 m1-12 m2-9 m2-10 }}$

$\begin{array}{lllllllllll}\mathrm{Ru} & 1.45 & 2.89 & 2.29 & 3.00 & 2.29 & 3.00 & 3.54 & 3.71 & 3.68 & 3.52 \\ \mathrm{Fe} & 1.45 & 2.79 & 2.08 & 2.86 & 2.07 & 2.92 & 3.33 & 3.44 & 3.39 & 3.48 \\ \mathrm{Os} & 1.46 & 2.88 & 2.28 & 3.07 & 2.28 & 3.07 & 3.58 & 3.56 & 3.57 & 3.58 \\ & & & & & & & & & & \\ & 9-\mathrm{m} 1-10 & 11-\mathrm{m} 2-12 & 4 \mathrm{a}-\mathrm{m} 1-4 \mathrm{~b} & 4 \mathrm{a}-\mathrm{m} 2-4 \mathrm{~b} & & & \\ \mathrm{Ru} & 89.5 & & 89.6 & & 26.7 & & 27.2 & & & \\ \mathrm{Fe} & 91.1 & & 91.8 & & 28.0 & & 28.9 & & & \\ \mathrm{Os} & 89.0 & & 88.9 & & 26.9 & & 26.9 & & & \end{array}$

$\begin{array}{lrrr}\text { C } & -0.075209586 & 5.819679506 & 0.214624080 \\ \text { C } & 0.672039494 & 3.663077352 & -0.268569104 \\ \text { C } & -0.500937655 & 4.499050138 & -0.145997883 \\ \text { C } & 1.818520121 & 4.493430686 & 0.024953154 \\ \text { C } & 1.350879487 & 5.816176424 & 0.319841918 \\ \text { H } & -0.724905718 & 6.680467399 & 0.360301254 \\ \text { H } & -1.530008206 & 4.182585954 & -0.301543871 \\ \text { H } & 2.857693469 & 4.171780655 & 0.022241497 \\ \text { H } & 1.976475718 & 6.673680183 & 0.559912587 \\ \text { C } & -0.085202153 & 0.051420723 & 0.179762476 \\ \text { C } & 0.669447039 & 2.210979431 & -0.277769075 \\ \text { C } & -0.506594056 & 1.378014443 & -0.163439279 \\ \text { C } & 1.813191497 & 1.372719333 & 0.003142165 \\ \text { C } & 1.341076152 & 0.048116080 & 0.282266572 \\ \text { H } & -0.737949797 & -0.808624988 & 0.315929496 \\ \text { H } & -1.534707743 & 1.700499108 & -0.312812885 \\ \text { H } & 2.853627814 & 1.690282875 & 0.002258526 \\ \text { H } & 1.963857816 & -0.814814832 & 0.509891379 \\ \text { Ru } & 0.514749017 & 4.370032193 & 1.892464141 \\ \text { Ru } & 0.513297393 & 1.477862765 & 1.874532702 \\ \text { C } & -0.917999510 & 4.525727369 & 3.130400230 \\ \text { O } & -1.812685226 & 4.683309022 & 3.863276385 \\ \text { C } & 1.750614063 & 4.523107729 & 3.327183819 \\ \text { O } & 2.528486900 & 4.679080791 & 4.183317677 \\ \text { C } & -0.916100902 & 1.308577885 & 3.114492723 \\ \text { O } & -1.808721861 & 1.142901872 & 3.848116198 \\ \text { C } & 1.753281443 & 1.306737715 & 3.303755557 \\ \text { O } & 2.533898990 & 1.140327190 & 4.155401562\end{array}$

$\begin{array}{rrrr}\text { C } & -0.079456 & 5.756047 & 0.317938 \\ \text { C } & 0.779399 & 3.656173 & -0.220539 \\ \text { C } & -0.433185 & 4.437260 & -0.117782 \\ \text { C } & 1.872018 & 4.520525 & 0.141772 \\ \text { C } & 1.335546 & 5.809070 & 0.478319\end{array}$


C 1.729444 .508273 .3123

O 2.514454 .674774 .1686

C - 0.8942621 .322333 .10227

O -1.795961 .146513 .83251$

C 1.731221 .300683 .29119

O 2.523951 .142764 .14136

\section{Analysis of Rate Equation Simulations}

To understand the kinetics of this reversal reaction upon thermal activation, we numerically solved Master equations in a three-state $\mathbf{2} \leftrightarrow \mathbf{B} \leftrightarrow \mathbf{1}$ model, using the reaction energetics determined by our calculations, with the whole distribution initially in state $\mathbf{2}$. The transition probability per unit time (rate constant) is given by transition state theory with a typical preexponential factor of $10^{12} \mathrm{~s}^{-1}$. This numerical simulation at $400 \mathrm{~K}$ predicts that the distribution in the intermediate state $\mathbf{B}$ reaches a steady state within 0.25 ns (see Figure S1). Therefore, the distributions in the states $\mathbf{2}$ and $\mathbf{1}$ begin to increase and decrease linearly with time, respectively. By fitting to $\mathrm{dP}_{1} / \mathrm{dt}=\mathrm{kP}_{2}$, where $\mathrm{k}$ is the effective rate constant and $\mathrm{P}$ is the distribution, we obtained an effective reaction barrier of $29.7 \mathrm{kcal} \mathrm{mol}^{-1}$ for the reversal reaction. This barrier constitutes the energy difference between the second $\mathrm{TS}_{\mathrm{B} \rightarrow 1}(\mathbf{C})$ and state 2 . Since $\mathrm{k}_{\mathrm{B} \rightarrow 2}$ is negligible compared to $\mathrm{k}_{\mathrm{B} \rightarrow 1}$ at this temperature and $\mathrm{k}_{1 \rightarrow \mathrm{B}}$ is also small, the Master equations simplify greatly. Together with the steady state approximation for state $\mathbf{B}$, which is valid almost instantly, we arrive at a simple expression relating $\mathrm{dP}_{1}$ and $\mathrm{P}_{2}$ to the effective rate constant given by $\mathrm{A}$ $\exp \left(E^{*} / k T\right)$, where $A$ is a preexponential constant and $E^{*}$ is the energy difference between the $\mathrm{TS}_{\mathrm{B} \rightarrow 1}$ and state 2 .

$$
\begin{aligned}
& \frac{d P_{1}}{d t}=k_{B \rightarrow 1} P_{B}-k_{1 \rightarrow B} P_{1} \\
& \frac{d P_{B}}{d t}=-k_{B \rightarrow 1} P_{B}-k_{B \rightarrow 2} P_{B}+k_{1 \rightarrow B} P_{1}+k_{2 \rightarrow B} P_{2} \\
& \frac{d P_{2}}{d t}=k_{B \rightarrow 2} P_{B}-k_{2 \rightarrow B} P_{2}
\end{aligned}
$$

Taking $k_{1 \rightarrow B}=0$, the equations simplify greatly for the time after the steady state is achieved $\left(d P_{B} / d t=0\right)$. Thus, the densities of states $\mathbf{1}$ and $\mathbf{2}$ can be related directly by

$$
\frac{d P_{1}}{d t}=\frac{k_{B \rightarrow 1} k_{2 \rightarrow B}}{k_{B \rightarrow 1}+k_{B \rightarrow 2}} P_{2}
$$

Since $k_{B \rightarrow 2}>>k_{B \rightarrow 1}$, the above equation can be reduced to

$$
\frac{d P_{1}}{d t} \approx \frac{k_{B \rightarrow 1} k_{2 \rightarrow B}}{k_{B \rightarrow 2}} P_{2}=k_{E f f e c t i v e} P_{2}
$$



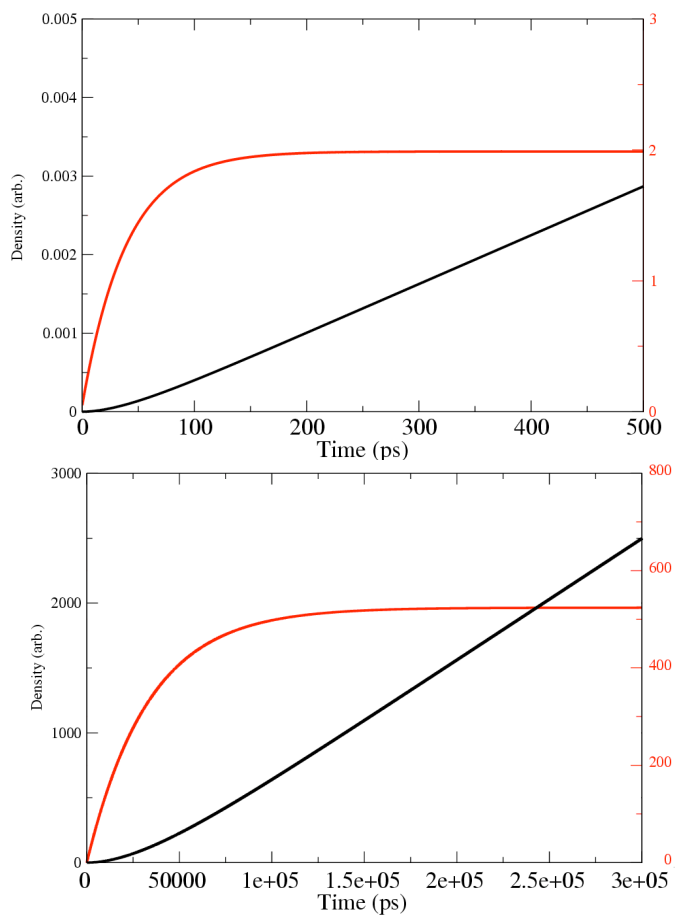

Figure S1: Time evolution of the density distributions for the thermal reversal reaction from state $\mathbf{2}$ and the intermediate state $\mathbf{B}$ in black and red, respectively, for Ru (top) and Fe (bottom).

and

$k_{\text {Effective }}=A \quad e^{-\beta\left(E_{2 \rightarrow B}^{*}+E_{B \rightarrow 1}^{*}-E_{B \rightarrow 1}^{*}\right)}$

The effective rate constant of the thermal reversal is $4.65 \times 10^{-4} / \mathrm{s}$ at $400 \mathrm{~K}$, while it is only $1.33 \times 10^{-9} / \mathrm{s}$ at $300 \mathrm{~K}$.

The thermal reversal was also computed explicitly for the Fe case. We again numerically simulated the kinetic behavior by solving the Master equations at $300 \mathrm{~K}$. In this case we find that the steady state in the intermediate state is not reached until $0.3 \mu$ s into the simulation. By monitoring $\mathrm{dP}_{1} / \mathrm{dt}=\mathrm{kP}_{2}$ in the linear regime, we obtain an effective barrier of approximately $17.3 \mathrm{kcal} \mathrm{mol}^{-1}$ with an effective rate constant of $1.20 / \mathrm{s}$ at 300 $\mathrm{K}$. This indicates an extremely fast rate of the thermal reversal reaction even at room temperature (several orders of magnitude faster than the $\mathrm{Ru}$ case), providing a possible explanation for the failure to detect state $\mathbf{2}$ experimentally. 